УДК 78.071.1(477):37.01

DOI:

Юрій Добуш, доцент кафедри методики музичного виховання і диригування Дрогобицького державного педагогічного університету імені Івана Франка

Зоряна Гнатів, кандидат філософських наук, доцент кафедри методики музичного виховання $і$ диригування Дрогобииького державного педагогічного університету імені Івана Франка

\title{
ТВОРИ В. ВИТВИЦЬКОГО ДЛЯ ДІТЕЙ: ПРОСВІТНИЦЬКО-ПЕДАГОГІЧНА СПЕЦИФІКА
}

Дослідження музикознавчої, композиторської та музично-громадської діяльності Василя Витвицького - вельми важливе завдання на нинішньому етапі пізнання й самоідентифікації начіональної культури: його постать уособлює генеральні напрямні й настановні позиції розбудови украӥнської музичної культури ХХ ст.

Музикознавчий доробок В. Витвицького - иінне надбання української музичної культури. Композиторська творчість В. Витвичького органічно вписується у його загальний портрет як музичного діяча, що має перед собою чітку мету: популяризувати українську пісню, утверджувати ії як трунт, на якому зросла й сформувалась украӥнська музична культура.

Ключові слова: Василь Витвицький; музичне мистецтвво; композиторська творчість; просвітництво; музика для дітей; педагогічна спещиифіка.

Jim. 5.

Yuriy Dobush, Associate Professor of the Methods of Music Education and Conducting Department, Drohobych Ivan Franko State Pedagogical University Zoryana Hnativ, Ph.D.(Philosophy), Associate Professor of the Methods of Music Education and Conducting Department, Drohobych Ivan Franko State Pedagogical University

\section{WORKS OF V. VITVYTSKIY FOR CHILDREN: EDUCATIONALAND PEDAGOGICAL SPECIFICS}

The study of musicological, compositional and musical-public activity of Vasyl Vytvytskiy is a very important task at the present stage of cognition and self-identification of national culture: his figure embodies the general guidelines and guidelines for the development of Ukrainian musical culture of the twentieth century.

Vytvytskiy is a valuable heritage of Ukrainian musical culture. His works cover a significant period of time: 1934-1989. V. Vytvytskiy's compositional work organically fits into his general portrait as a musical figure with a clear goal: to popularize Ukrainian song, to establish it as the ground on which Ukrainian musical culture grew and formed. At the same time, $V$. Vytvytskiy defends the principles of professionalism of composer's creativity, resorting to various means of spreading folk songs. It is the folk song that becomes the basis of all genres of his work. The composer turns to the method of direct citation, as well as to individual rethinking and generalization of folklore material. V. Vytvytskiy's works are also represented by genres of chamber and instrumental music. In addition, the composer is the author of individual vocal and choral works, as well as music for children's performances.

$V$. Vytvytskiy pays considerable attention to the enrichment of the pedagogical repertoire. The vast majority of the composer's works are addressed to Ukrainian youth, children, and the stratum organization. It is here that the popularizing orientation of $V$. Vytvytskiy's work is most fully revealed.

$V$. Vytvytskiy's author's songs are closely connected with the progressive ideas of his time. They embody the ideas of patriotism and civic duty, a sense of intolerance of violence and oppression.

$V$. Vytvytskiy's songs are intended for a wide range of music lovers. Hence - the expressiveness of melody, simplicity of musical expression, conciseness of form.

Keywords: Vasyl Vytvytskiy; musical art; composition; education; music for children; pedagogical specifics.

П остановка проблеми: Акцентування персоналістського досвіду Василя Витвицького - як музикознавця, композитора та музично-громадського діяча - в моделі та буттєвому статусі української музичної культури має на сьогодні досить часті спроби. Однак спеціальних видань, присвячених саме так окресленій проблемі, не лише немає, але й

(C) Ю. Добуш, 3. Гнатів, 2021 висвітлюється вона переважно як окремі аспекти. Проте цілісного дослідження стосовно постаті В. Витвицького в контексті соціокультурної ситуації першої половини ХХ ст. - особливо 3 точки зору особистісного внеску й ролі у становленні національної музичної свідомості на сьогодні не існує. Особливої уваги заслуговує музична спадщина В. Витвицького для дітей. 
Аналіз наукових праць 3 проблемами дослідження. Початок роботи над цією проблемою було покладено в окресленнях найбільш важливих напрямів наукового пошуку. Так, вагомим досягненням сучасної музикознавчої думки став початок досліджень Галицької музичної культури (М. Черепанин, Л. Кияновська, О. Козаренко, О. Шевчук). Загальній характеристиці постаті В. Витвицького присвячені такі праці: “В. Витвицький музикознавець” М. Зубеляк [3], “В. Витвицький - митець і вчений” Л. Лехника [4], “В. Витвицький” Я. Михальчишина [5] та ін.

Мета статті - визначити особливості музикознавчої, композиторської та музичнопросвітницької діяльності Василя Витвицького для дітей як такої, що становить вагому компоненту персоналістського досвіду української культури в справі її розвою й покріплення національної ідентичності.

Виклад основного матеріалу. Відродження єдиного етнокультурного простору в нашій незалежній Українській державі висувається в ранг найактуальніших суспільно-політичних проблем, набуває окремого наукологічного статусу і потребує виваженого й різнобічного вивчення. Трансформаційні умови українського соціуму нашого часу не тільки створили зовсім нову ситуацію для розвитку національної музикознавчої думки, але й поставили перед дослідниками цілу низку актуальних завдань, розв'язання яких, з відомих причин, довго i, здавалося б, безнадійно залишалося неможливим - бо було "не дозволеним".

Активна діяльність В. Витвицького в ділянці музикознавства та музично-громадському житті обмежувала міру прикладання його зусиль у сфері композиторської творчості. Тому, порівняно 3 музикознавством, безпосередньо композиторська діяльність є менш об'ємною у його загальній творчій спадщині.

Однак характеризуючи, наприклад, творчість композитора з боку способів самого “контактування" 3 фольклорним матеріалом, застосовуватимуться порівняння з близькими за жанром творами інших композиторів - В. Барвінського, Л. Ревуцького та iн.

Композиторська творчість В. Витвицького органічно вписується у його загальний портрет як музичного діяча демократичного спрямування, що має перед собою чітку мету: популяризувати українську пісню, утверджувати ії як грунт, на якому зросла й сформувалась українська музична культура. Водночас В. Витвицький відстоює засади професіоналізму композиторської творчості, вдаючись до різноманітних засобів поширення народної пісні. Вона стає основою усіх жанрів його творчості. Композитор звертається як до методу прямого їі цитування, так і до індивідуального переосмислення та узагальнення фольклорного матеріалу.

Твори В. Витвицького у своїй більшості репрезентують жанри камерно-інструментальної музики. Крім того, він є автором окремих вокально-хорових творів, а також музики до дитячих вистав. В. Витвицький надає значну увагу збагаченню педагогічного репертуару. Просвітницьку мету композитора посвідчує часте звернення до 4-ручного викладу фортепіанних п’єс. Технічно менше складні, вони стають доступнішими до виконання, а те, зі свого боку, сприяє поширенню українського фортепіанного репертуару в домашньому музикуванні. Як свідчать “Спогади”, В. Витвицький сам залюбки грав “у чотири руки”.

В. Витвицький постійно вболіває за долю української музики; докладає зусиль, щоб піднести стан української музичної культури на вищий рівень і включити їі до світового музичного процесу. Так, на початку 30-х рр. у Галичині виникли численні хорові осередки, керівництво якими здійснювали переважно музикантиаматори. Це викликало нагальну потребу у відповідному методичному посібнику для хормейстерів. Так зїявився “Диригентський порадник” (1938) - у співпраці В. Витвицького, М. Колесси та Зеновія Лиська під загальною редакцією В. Витвицького. Як зазначено у передмові, основні зусилля митців мали бути спрямовані на піднесення хорового життя Західної України: “Для цієї ціли першорядне значення має відповідний вишкіл провідників міських і сільських співацьких гуртків. Спричинитися до цього, дати фахову пораду в найважливіших справах диригентської праці - це і є завданням нашого Порадника" [Д. I.: 5, 5].

Слушно вважати, що дитячі роки - це той час, коли можна найбільш успішно прищепити любов до музики, навчити розуміти іï, впливати за її допомогою на особистість. Тому значна більшість творів композитора адресована українській молоді, дітям, пластовій організації. Саме тут популяризаторська спрямованість творчості В. Витвицького виявляється найбільш повно.

Дві збірки обробок украӥнських народних пісень для фортепіано в 4 руки (Перший випуск з'явився у Львові 1944 р. у черговому випуску збірки “Український Педагогічний репертуар", другий - 1974p. у Торонто) є досить цікавими щодо 
підходу композитора до фольклорного матеріалу. В. Витвицький виявляє інтерес до різноманітних народнопісенних жанрів (календарно-обрядові, родинно-побутові, жартівливо-танцювальні, історичні), та перевагу надає дитячому фольклору. Автор відбирає пісні з “простими” ладоінтонаційними та метро-ритмічними засобами, причому користується найбільш відомими мелодичними варіантами.

Композиційна форма п'єс проста - строфічна 3 елементами варіаційного розвитку або тричастинна, часто з репризним обрамленням. Фактура здебільшого гомофонно-гармонічна, подекуди - 3 використанням поліфонічних прийомів: підголосковості (“Марш”, “Ой у полі”у Другій збірці), канонічної та вільної імітації (“У лузі”, “Данчик” - з Першої збірки). Найбільш виразно підголоскова манера народного багатоголосся проглядає в п’єсі “Ой у полі, полі”: збереження закономірностей народного голосоведення допомагає дітям засвоювати специфічні особливості національної традиції гуртового (хорового) співу. Примітно також, що подекуди художній зміст першоджерела опрацьовується засобом аранжування - із застосуванням різноманітних звукозображальних прийомів. Так, у багатьох п’єсах “нехитра” мелодія поєднується із ускладненою гармонією. В окремих випадках такі гармонічні загострення є умисними, і не завжди “виправданими” (у п’єсі “Щиглик”, наприклад).

“Характеризовані” п'єси розташовуються у збірках за певною логічною послідовності. У Першій збірці, окрім образного контрастування п’єс, - це тональпий принции (як тут не згадати ідею структурування Добре темперованого клавіру Й. Баха!) - у напрямі “зростання” ключових знаків при поєднанні паралельних (мажорної та мінорної) тональностей. У Другій збірці п’єси розташовані насамперед за принципом образного контрастування, що як “ідея” здобуває конкретизацію у темповому і ладотональному контрастуванні.

Обидві збірки обробок В. Витвицького свідчать про еволюцію автора щодо мистецького втілення народнопісенного матеріалу. Зокрема, п’єси Другої збірки мають різноманітнішу й складнішу фактуру, більш розгорнуту композиційну будову. Тут композитор досягає органічного поєднання фольклорної стилістики минулого із сучасними гармонічними, наприклад, засобами, які він уміло поєднує.

Цікавою в дитячому репертуарі В. Витвицького є Сонатина для фортепіанного дуету, в якій композитор звертається до класичної жанрової форми, яку втілює “засобом” українського національного “матеріалу”. Як і в більшості оригінальних творів В. Витвицького, у Сонатині зв'язки 3 фольклором виступають опосередковано: композитор вдається радше до стилізації “лексики” лірико-пісенних та танцювальних жанрів.

У Сонатині В. Витвицький застосовує принцип викладу тематичного матеріалу, що полягає в ладо-тональному розвиткові тематичного “зерна”, причому часто використовуються тональності мажоро-мінорної спорідненості. Сдність циклу зумовлюють також інтонаційні арки.

Загалом яскравий мелодизм Сонатини, iï пісенно-танцювальна основа, світлий колорит та зручна піаністична фактура цілком відповідають дитячому сприйняттю й виконавству.

3 педагогічною метою В. Витвицьким була написана Сюїта для скрипки, віолончелі та фортепіано. Твір складається 3 чотирьох частин, кожна 3 яких має програмну назву: Спомин, Інтерлюдія, Колискова, Фінал. Жанрове визначення твору декларує сюїтний принцип побудови циклу: чергування (“ряд”, послідовність) iз взаємодоповненням та зіставленням різнохарактерних “картин”. Внутрішня структура кожного номера сюїти однотипна - тричастинна форма із розвитковим контрастом. В. Витвицький застосовує різноманітні прийоми розгортання музичної думки: варіаційність, секвенціювання, поліфонічність (прийоми підголосковості, імітації, контрапункту, стретне проведення).

У Сюїті В. Витвицький не вдається до цитування, але активно перетворює і трансформує фольклорні елементи. Так, у Спомині та Колисковій композитор відштовхується від “лексики” українського ліричного мелосу; у контрастних за характером Інтерлюдії та Фіналі - спирається на народно-танцювальні образи.

Розрахована на дитяче виконання, Сюїта відзначається простотою гармонічних та фактурних засобів. У розвитку музичного тематизму твору всі три інструменти є самостійними, індивідуалізованими (причому партія фортепіано цементує всю музичну тканину і вносить певні ілюстративні штрихи). Динамізація досягається пошуками щоразу нових тембрів та звукових барв: одна й та ж тема "проводиться" різними інструментами ансамблю.

Послідовно дотримуючись принципу організації музичного навчання українських дітей на основі народної творчості, В. Витвицький пише також музику до дитячих вистав. Прикладом цього є казка Н. Забіли "Півник і курочка". Тут всього 
два музичні номери: пісня Курочки, яка повторюється кілька разів, та фінальна пісня героїв вистави - Півника, Курочки, Зайчика і Білочки. Вистава адресована найменшій дитячій аудиторії - як слухачам, і як виконавцям. Звідси - простота й виразність мелодій, чіткість та музичних номерів вистави покладено народнопісенні інтонації, тобто В. Витвицький знову звертається до українського фольклору.

У текстовому викладі “Спогадів” В. Витвицького, що відомі під назвою видання "Музичними шляхами”, є такий запис: “...була одна редакціiйна робота, яку я виконував 3 немалою дозою сентименту. То була праця над "Пластовим співаником”. Як колишній завзятий пластун, я знав 3 власного досвіду, які є потреби і якості належного пісенного репертуару для пластової молоді. 3 виключенням кількох десятків нових пісень різних авторів співаник під назвою “В дорогу” (1949) вийшов доволі показовим” $[1,132]$.

“Співаник” з'явився в Агсбургу, у пластовім видавництві “Молоде життя”. У передмові до нього сказано: "Пісня - куди більше як обличчя, мова чи зверхній вигляд віддзеркалює душу і вдачу людини. Вона говорить не тільки про національну приналежність даної людини, але теж і про цілий нарід, про його духовність і культуру. Тому не однаково що співатиме наше юнацтво і не однаково, як співатиме воно свої пісні. До співу українських пластунів прислухатимуться чужинці. I тим уважніше треба нам ставитись до наших пісень і їх виконування. Отже, “Пластовий співаник” постав як відповідь на вимогу часу: залучати молодь до активної громадської діяльності за допомогою пісні.

В. Витвицький зібрав і зредагував 1-4 та 6 розділи співаника, до якого увійшли також три його ж пісні - "Зірвалася хуртовина", "Нема тії сили" та "Віють прапори"; а також обробка пісні В. Верховинця на слова М. Хвильового “Ой, зацвіла папороть”. До своїх пісень композитор використав тексти поетів I. Багряного, Г. Чупринки.

Авторські пісні В. Витвицького тісно пов'язані з прогресивними ідеями свого часу, надіями та тривогами творчої інтелігенції. У них втілені ідеї патріотизму і громадянського обов'язку, почуття непримиренності до насильства й гноблення.

Пісні В. Витвицького призначені для широкого кола любителів музики. Звідси - виразність мелодики, простота музичного вислову, лаконічність форми. Інтонації грунтуються на матеріалі народних пісень, зокрема - похідних маршових із типовими для них образами мужності. Від народних козацьких пісень - чотири чи дводольний метр; поєднання широких мелодичних зворотів із чіткою, карбованою ритмікою похідної пісні. Вокальна мелодика наслідує закличні мотиви бойової сурми (рух стійкими щаблями), будується на пружних висхідних квартових інтонаціях. Мелодичні побудови відзначаються тональною стійкістю 3 невеликими відхиленнями у найближчі тональності, структурною завершеністю 3 чіткими кадансовими закінченнями, часто октавними. У фортепіанному супроводі композитор застосовує типово маршовий акордово-гармонічний виклад з підкресленням кожної долі такту. Форма пісень проста, строфічна. Інструментальний вступ накреслює основне ритмоінтонаційне зерно пісні.

Поява "Пластового співаника” була небуденною подією в музичному житті української діаспори. Крім прикладного значення, Співаник виконує і просвітницьку функцію. Він покликаний залучити до музичного мистецтва найкращі кола громадськості, репрезентувати українську пісенну культуру в еміграції. Тому не випадково Співаник містить статтю В. Витвицького "Українська музика", де автор у популярній формі прилучає читача до історії українського музичного мистецтва - починаючи з часів княжої доби, знайомить читачів із творчістю провідних українських композиторів: М. Березовського, Д. Бортнянського, А. Веделя, М. Лисенка, М. Леонтовича, С. Людкевича.

Висновки. Уся багатогранна музикознавча, композиторська, педагогічна, громадська діяльність В. Витвицького нагально стверджують його належність до ряду послідовників Лисенкової традиції на новому історичному етапі: як і основоположник української класики, він надає постійної уваги всім ділянкам музичнокультурного життя. Чітка позиція митцягромадянина визначила напрями й провідну ідею творчої спадщини В. Витвицького загалом: максимально розкрити, утвердити надбання вітчизняної культури, повернути їх рідному народові і пропагувати досягнення української культури та мистецтва за кордоном.

Підсумовуючи, констатуємо, що В. Витвицький має чималі заслуги в обріях української культури. Шлях його життя проходить крізь бурхливу добу світових воєн, політичних катаклізмів, національновизвольних змагань українського народу, вимушеної еміграції. Проте навіть за найскладніших умов В. Витвицький, як митецьгромадянин, був віддано вірним вітчизняній музичній культурі -iï національно-осібному духові 
й виразу, з власним характером поступу й метою.

\section{ЛІТЕРАТУРА}

1. Витвицький В. Музичними шляхами: Спогади. Мюнхен: Бібліотека Прологу i Сучасности, 1989. Ч. 183.216с.

2. Витвицький В., Колесса М., Лисько 3. під заг. ред. В. Витвицького. Диригентський порадник. Львів: Український видавничий інститут, $1938.240 \mathrm{c}$.

3. Зубеляк М. Витвицький - музикознавець. За океаном: зб. статей. Львів, 1996. С. 3-8.

4. Лехник Л. В. Витвицький - митець і вчений. Музикознавчі праці. Публіцистика. Львів, 2003. C. $8-18$.

5. Михальчишин Я. В. 3 музикою крізь життя. Львів, 1992. С. 211-214.

\section{REFERENCES}

1. Vytvytskyi, V. (1989). Muzychnymy shliakhamy: Spohady [Musical ways: Memories]. Miunkhen, part. 183, p. 216. [in Ukrainian].

2. Vytvytskyi, V., Kolessa, M. \& Lysko, Z. (1938). Dyrygentskyi poradnyk [Conducting advisor]. Lviv, p. 240. [in Ukrainian].

3. Zubeliak, M. (1996). Vytvytskyi muzykoznavets [Vytvytskiy - musicologist]. Overseas: Coll. articles. Lviv, pp. 3-8. [in Ukrainian].

4. Lekhnyk, L. (2003). V. Vytvytskyi - mytets i vchenyi [Vytvytskiy is an artist and scientist]. Musicological works. Journalism. Lviv, pp. 8-18. [in Ukrainian].

5. Mykhalchyshyn, Ya. (1992). Z muzykoiu kriz zhyttia [With music through life]. Lviv, pp. 211-214. [in Ukrainian].

Стаття надійшла до редакції 16.08.2021

УДК 378.011.3-051

DOI:

Марія Ярушак, кандидат педагогічних наук, доцент кафедри загальної педагогіки та дочкільної освіти Дрогобицького державного педагогічного університету імені Івана Франка

\section{ЗАСТОСУВАННЯ КОМПЕТЕНТНІСНОГО ПІДХОДУ У ПРОЦЕСІ ПІДГОТОВКИ ФАХІВЦІВ ЗАКЛАДІВ ВИЩОЇ ОСВІТИ}

У статті окреслено особливості реалізації компетентнісного підходу в умовах підготовки фахівців закладів вищої освіти. Представлено аналіз термінологічної єдності дослідників щооо сутнісних характеристик поняття “компетентнісний підхід”, як вплив на особистісні якості та утворення, яка при достатній мотивації забезпечує прочес самореалізації, самозбереження і самовдосконалення особистості студента в процесі професійної діяльності. Окреслено особливості застосування компетентнісного підходу крізь призму практичного досвіду.

Встановлено, щзо реалізація компетентнісного підходу можлива, якщз зміст, методи і організаційні форми навчання, а також діяльність студентів будуть значимі, тобто навчальний процес матиме професійноособистісну спрямованість.

Ключові слова: заклади вищої освіти; компетентнісний підхід; навчання; професійна підготовка; фахіви̧і.

Jim. 12.

Maria Yarushak, Ph.D.(Pedagogy), Associate Professor of the General Pedagogy and Preschool Education Department of Drohobych Ivan Franko State Pedagogical University

\section{APPLICATION OF COMPETENCE APPROACH IN THE PROCESS OF TRAINING PROFESSIONALS OF HIGHER EDUCATION INSTITUTIONS}

The article deals with the peculiarities of the implementation of the competence approach in the conditions of training specialists of higher education institutions. An analysis of the terminological unity of researchers on the essential characteristics of the concept of "competence approach" as an impact on personal qualities and education, which with sufficient motivation provides a process of self-realization, self-preservation and self-improvement of the student's personality in the process of professional activity. Peculiarities of application of the competence approach through the prism of practical experience have been outlined.

It is established that the implementation of the competence approach is possible if the content, methods and organizational forms of learning, as well as the activities of students are significant, the learning process will have 